\title{
Application of Chitosan in Food Preservation
}

\author{
A. Reni Prabha ${ }^{1}$, K. Sivakumar ${ }^{2}$ \\ P.G. and Research Department of Zoology, Chikkaiah Naicker College, Erode.638011
}

\begin{abstract}
In the present investigation, chitosan from prawn shell waste was analysed for its preservative potential in vegetables. Studies have been carried out to determine the aging and textural changes in Brinjal, Capsicum and Tomato under the effect of chitosan treatment. After the experimental exposure, the control vegetables have turned soft in texture whereas no such changes have been observed in the chitosan sprayed vegetables even at the end of $8^{\text {th }}$ day of observation. Chitosan caused delayed ripening and reduced decay incidence. Thus chitosan can be used as a potential preservative for agricultural products.
\end{abstract}

Keywords: Chitosan, Preservative potential, Brinjal, Capsicum and Tomato

\section{Introduction}

The postharvest loss of many fruits and vegetables is due to their perishable nature. During storage and transport, they undergo fungal infection, physiological disorders and physical injuries.

Many such post harvest produce are kept in moderately low temperatures and high humidity. However commodities such as tomatoes undergo chilling injury [1]. Atmospheric modification with low $\mathrm{O}_{2}$ and $\mathrm{CO}_{2}$ is carried out as an alternative method to prolong the shelf life [2]. It can be done through plastic film packaging and by individual coating with wax, sucrose fatty esters [3], [4].

Among the promising approaches for inducing plant disease resistance and stimulate the immunity of plant to increase its shelf life is Chitosan [5]. Chitosan, obtained by deacetylation of Chitin, might be an ideal preservative coating for fresh fruits and vegetables because of its filmforming and biochemical properties [6].

Chitosan is natural polysaccharides, which consists of a copolymer of $\mathrm{N}$-acetyl-D-glucosamine and D-glucosamine residues linked by $\beta-1,4$ glycosidic bonds [7].

Furthermore, Chitosan is considered to be a safe material as indicated by toxicological studies [8]. Hence, this substance has potential as a post harvest coating material in food preservation.

Earlier, the effect of Chitosan has been studied for the inhibition of sclerotinia rot of carrots [9]. Its effect on strawberries [10], peas [11], tomatoes [10] and cucumber [12] has been studied.

The objective of this paper was to determine the effect of Chitosan on the aging of Brinjal, Capsicum and Tomato over a period of 8 days.

\section{Materials and Methods}

Chitosan solutions were prepared by dissolving Chitosan $(1 \%$ \& $3 \%(\mathrm{w} / \mathrm{v}))$ in $0.25 \mathrm{~N} \mathrm{HCl}$. The solution was centrifuged to remove undissolved particles and the $\mathrm{pH}$ was adjusted to 5.6 with $1 \mathrm{~N} \mathrm{NaOH}$. At this $\mathrm{pH}$, Chitosan is positively charged and exhibits maximal biological activity [13].

The samples namely brinjal, capsicum and tomato were taken. The vegetable samples were coated with $1 \%$ and $3 \%$ Chitosan solution. Control sample was kept without any coating on the surface. The vegetables were monitored carefully for the effect of Chitosan.

\section{Results and Discussions}

Table 1: Effect of Chitosan on Brinjal

\begin{tabular}{|c|c|c|c|c|}
\hline S.No & Day & Control & $1 \%$ Chitosan & $\begin{array}{c}3 \% \\
\text { Chitosan }\end{array}$ \\
\hline 1 & First Day & No Change & No Change & No Change \\
\hline 2 & Second Day & No Change & No Change & No Change \\
\hline 3 & Third Day & $\begin{array}{c}\text { Wrinkles were } \\
\text { formed }\end{array}$ & No Change & No Change \\
\hline 4 & Fourth Day & $\begin{array}{c}\text { Wrinkles were } \\
\text { formed }\end{array}$ & No Change & No Change \\
\hline 5 & Fifth Day & $\begin{array}{c}\text { Deep wrinkles were } \\
\text { formed }\end{array}$ & No Change & No Change \\
\hline 6 & Sixth Day & $\begin{array}{c}\text { Wrinkles have been } \\
\text { developed more } \\
\text { deeply }\end{array}$ & No Change & No Change \\
\hline 8 & Seventh Day & $\begin{array}{c}\text { Soft in texture, deep } \\
\text { wrinkles and size } \\
\text { began to shrink }\end{array}$ & $\begin{array}{c}\text { No } \\
\text { significant } \\
\text { changes } \\
\text { observed }\end{array}$ & No Change \\
\hline Eighth Day & $\begin{array}{c}\text { Deep wrinkles, size } \\
\text { shrunk }\end{array}$ & $\begin{array}{c}\text { No } \\
\text { significant } \\
\text { changes } \\
\text { observed }\end{array}$ & No Change \\
\hline
\end{tabular}

It is observed from the results that over the span of 8 days, the signs of aging have appeared in the control whereas no such changes have been seen in both the Chitosan sprayed brinjal.

Table 2: Effect of Chitosan on Capsicum

\begin{tabular}{|c|c|c|c|c|}
\hline S.No. & Day & Control & $\begin{array}{c}1 \% \\
\text { Chitosan }\end{array}$ & $\begin{array}{c}3 \% \\
\text { Chitosan }\end{array}$ \\
\hline 1 & $\begin{array}{c}\text { First } \\
\text { Day }\end{array}$ & No Change & No Change & $\begin{array}{c}\text { No } \\
\text { Change }\end{array}$ \\
\hline 2 & $\begin{array}{c}\text { Second } \\
\text { Day }\end{array}$ & $\begin{array}{c}\text { Wrinkles have started } \\
\text { to appear }\end{array}$ & No Change & $\begin{array}{c}\text { No } \\
\text { Change }\end{array}$ \\
\hline 3 & $\begin{array}{c}\text { Third } \\
\text { Day }\end{array}$ & $\begin{array}{c}\text { Wrinkles have formed } \\
\text { No Change }\end{array}$ & $\begin{array}{c}\text { No } \\
\text { Change }\end{array}$ \\
\hline 4 & $\begin{array}{c}\text { Fourth } \\
\text { Day }\end{array}$ & $\begin{array}{c}\text { Wrinkles were formed } \\
\text { and size began to }\end{array}$ & No Change & $\begin{array}{c}\text { No } \\
\text { Change }\end{array}$ \\
\hline
\end{tabular}




\section{International Journal of Science and Research (IJSR) \\ ISSN (Online): 2319-7064}

Index Copernicus Value (2015): 78.96 | Impact Factor (2015): 6.391

\begin{tabular}{|c|c|c|c|c|}
\hline 5 & $\begin{array}{c}\text { Fifth } \\
\text { Day }\end{array}$ & $\begin{array}{c}\text { Size has shrunken } \\
\text { significantly, wrinkles } \\
\text { have developed }\end{array}$ & $\begin{array}{c}\text { Very small } \\
\text { wrinkles } \\
\text { start to } \\
\text { appear }\end{array}$ & $\begin{array}{c}\text { No } \\
\text { Change }\end{array}$ \\
\hline 6 & $\begin{array}{c}\text { Sixth } \\
\text { Day }\end{array}$ & $\begin{array}{c}\text { Has turned soft, well } \\
\text { developed wrinkles } \\
\text { and colour began to } \\
\text { deteriorate, size has } \\
\text { shrunken. }\end{array}$ & $\begin{array}{c}\text { Small } \\
\text { wrinkles } \\
\text { remains } \\
\text { same }\end{array}$ & $\begin{array}{c}\text { No } \\
\text { Change }\end{array}$ \\
\hline 7 & $\begin{array}{c}\text { Seventh } \\
\text { Day }\end{array}$ & $\begin{array}{c}\text { Size began to shrink } \\
\text { severely soft, wrinkles } \\
\text { texture appeared }\end{array}$ & $\begin{array}{c}\text { Wrinkles } \\
\text { have } \\
\text { appeared }\end{array}$ & $\begin{array}{c}\text { Small } \\
\text { wrinkles } \\
\text { started to } \\
\text { appear }\end{array}$ \\
\hline 8 & $\begin{array}{c}\text { Eighth } \\
\text { Day }\end{array}$ & $\begin{array}{c}\text { Size was shrunken well } \\
\text { and wrinkles were very } \\
\text { deep }\end{array}$ & $\begin{array}{c}\text { Wrinkles } \\
\text { have } \\
\text { appeared }\end{array}$ & $\begin{array}{c}\text { Wrinkles } \\
\text { have } \\
\text { appeared }\end{array}$ \\
\hline
\end{tabular}

Table 3: Effect of Chitosan on Tomato

\begin{tabular}{|c|c|c|c|c|}
\hline S.No. & Day & Control & $1 \%$ Chitosan & $\begin{array}{c}3 \% \\
\text { Chitosan }\end{array}$ \\
\hline 1 & First Day & No Change & No Change & No Change \\
\hline 2 & $\begin{array}{c}\text { Second } \\
\text { Day }\end{array}$ & No Change & No Change & No Change \\
\hline 3 & $\begin{array}{c}\text { Third } \\
\text { Day }\end{array}$ & No Change & No Change & No Change \\
\hline 4 & $\begin{array}{c}\text { Fourth } \\
\text { Day }\end{array}$ & No Change & No Change & No change \\
\hline 5 & Fifth Day & No Change & No Change & No change \\
\hline 6 & $\begin{array}{c}\text { Sixth Day } \\
\text { Has started } \\
\text { to turn soft }\end{array}$ & No Change & No change \\
\hline 7 & $\begin{array}{c}\text { Seventh } \\
\text { Day }\end{array}$ & $\begin{array}{c}\text { Soft in } \\
\text { texture }\end{array}$ & No Change & No change \\
\hline 8 & $\begin{array}{c}\text { Eight Day } \\
\text { Soft in } \\
\text { texture }\end{array}$ & No Change & No change \\
\hline
\end{tabular}

It can be observed that the aging process of the control fruit on begun on the second day with the formation of wrinkles whereas on the capsicum with $1 \%$ Chitosan, wrinkles begin to appear only on the fifth day. 3\% Chitosan sprayed capsicum shows wrinkle formation only on the seventh day.

It can be observed that at the end of eighth day of observation, the control has turned soft in texture whereas no such changes have been observed in the Chitosan sprayed tomatoes. while the Chitosan sprayed capsicums appear with wrinkles.

\section{BRINJAL}

Figure 1: Day 1

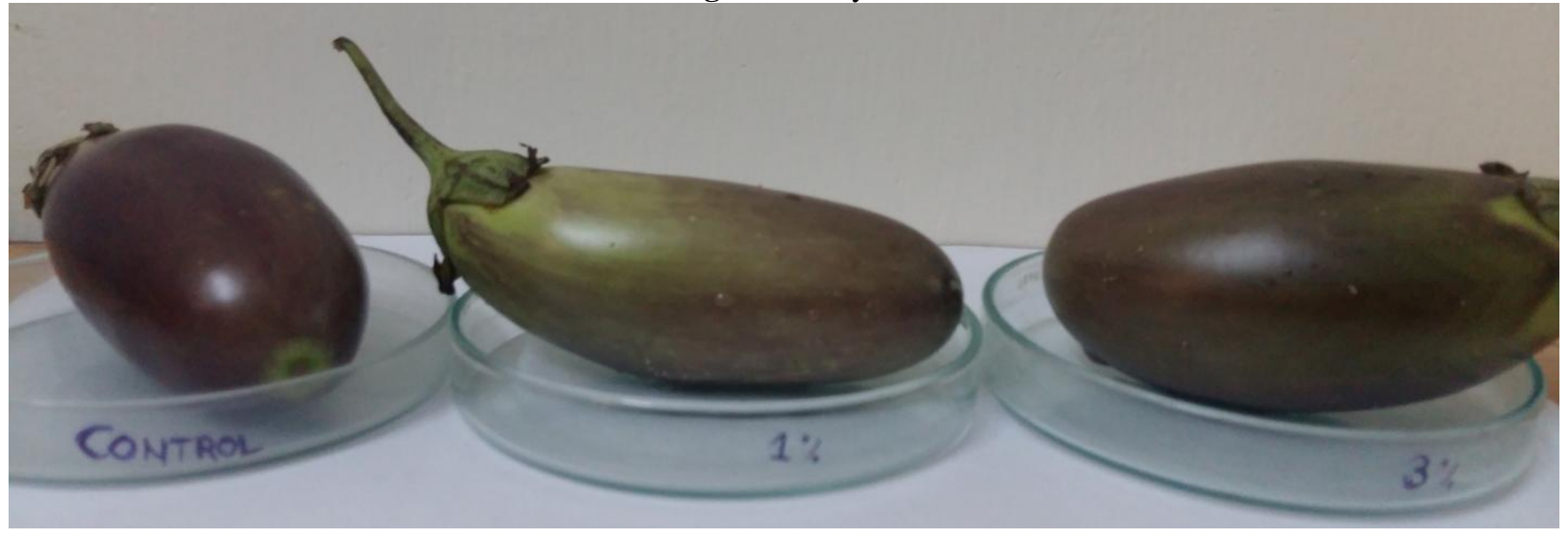

Figure 2: Day 2

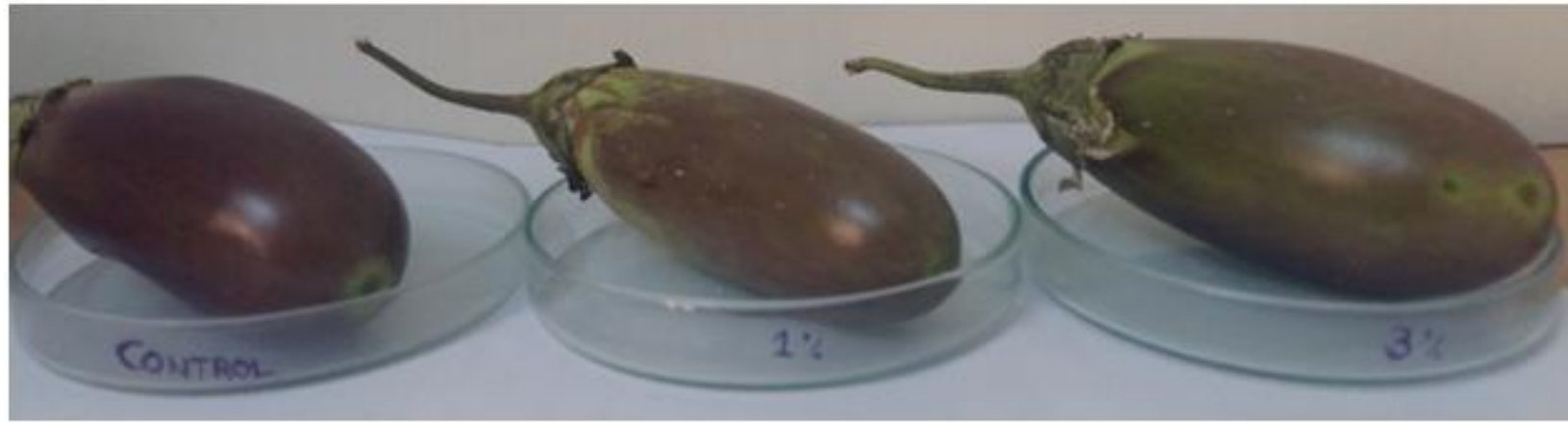


International Journal of Science and Research (IJSR)

ISSN (Online): 2319-7064

Index Copernicus Value (2015): 78.96 | Impact Factor (2015): 6.391

Figure 3: Day 3

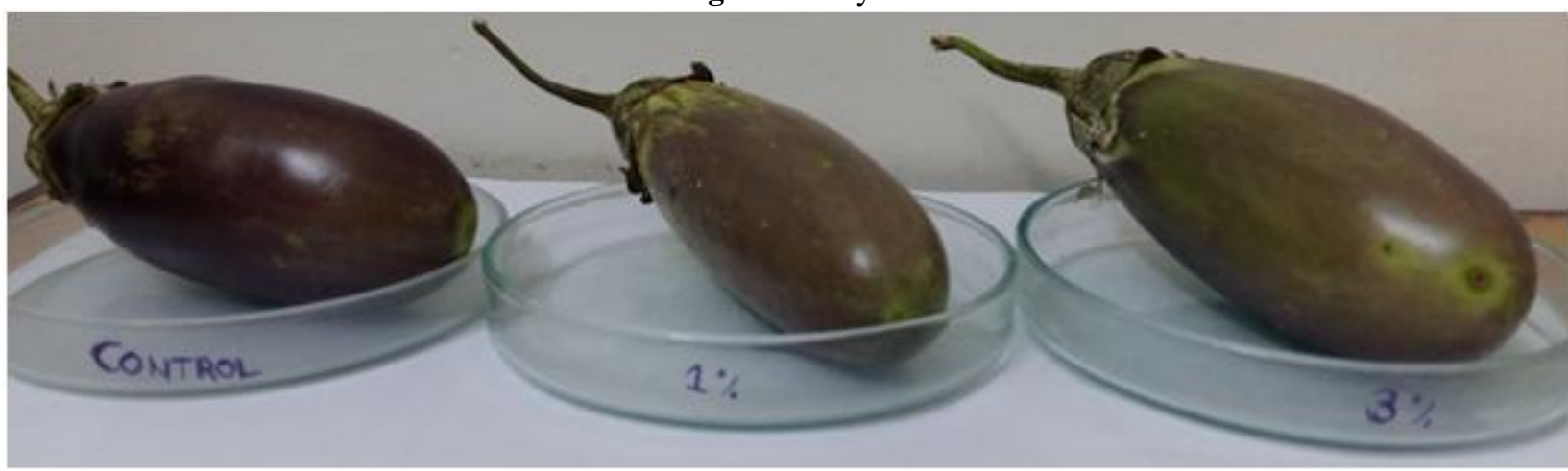

Figure 4: Day 4

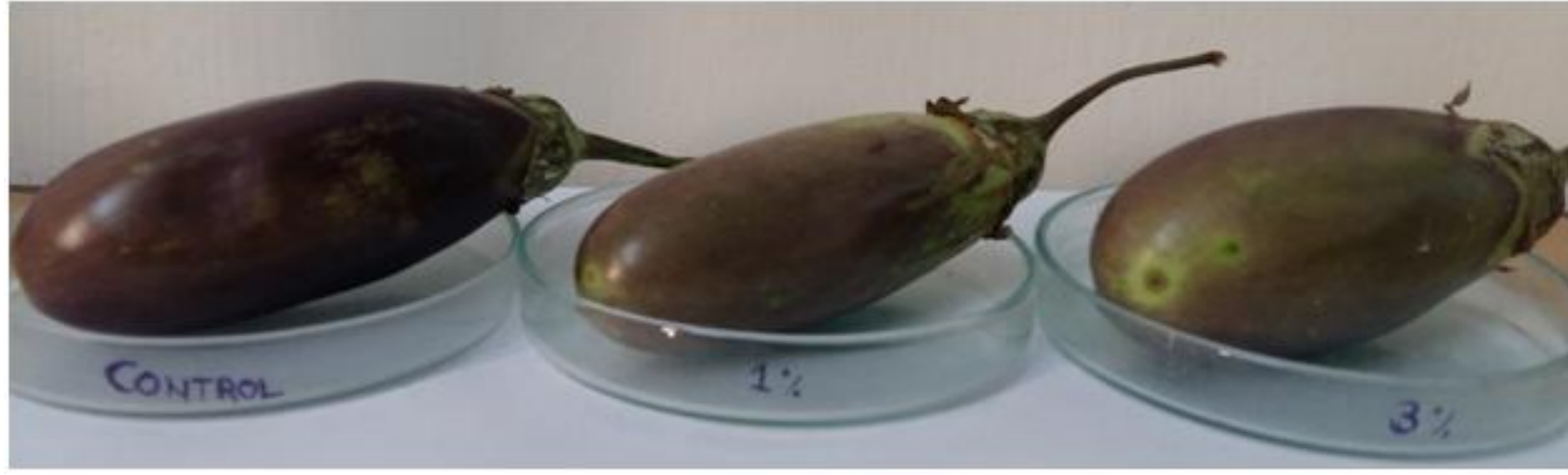

Figure 5: Day 5

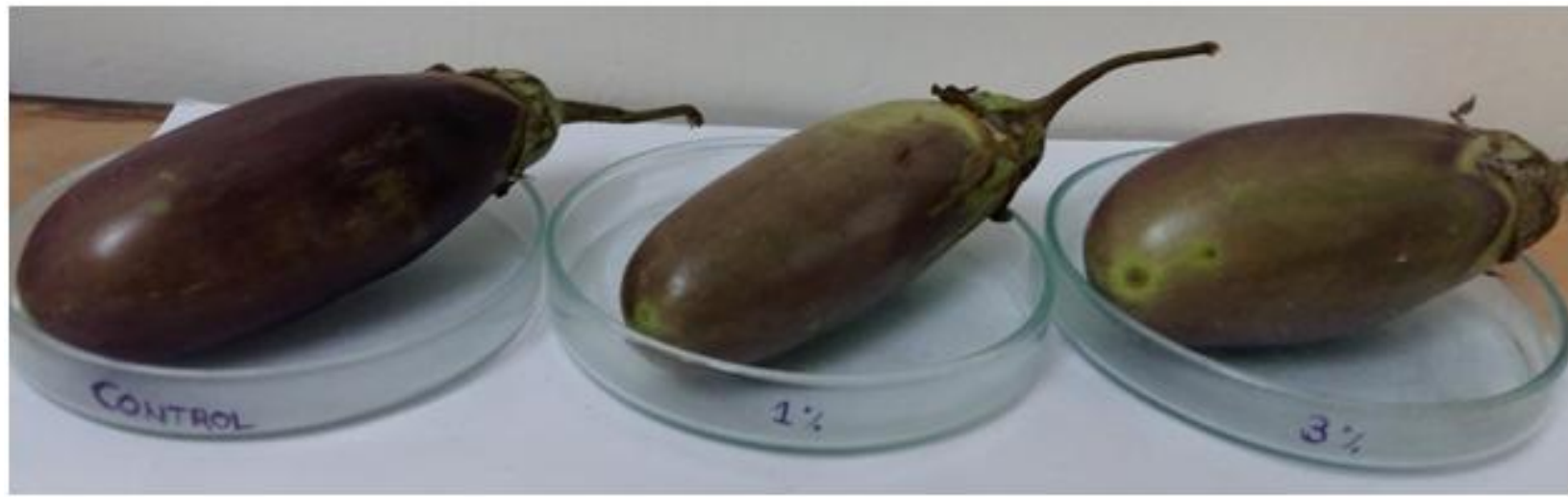

Figure 6: Day 6

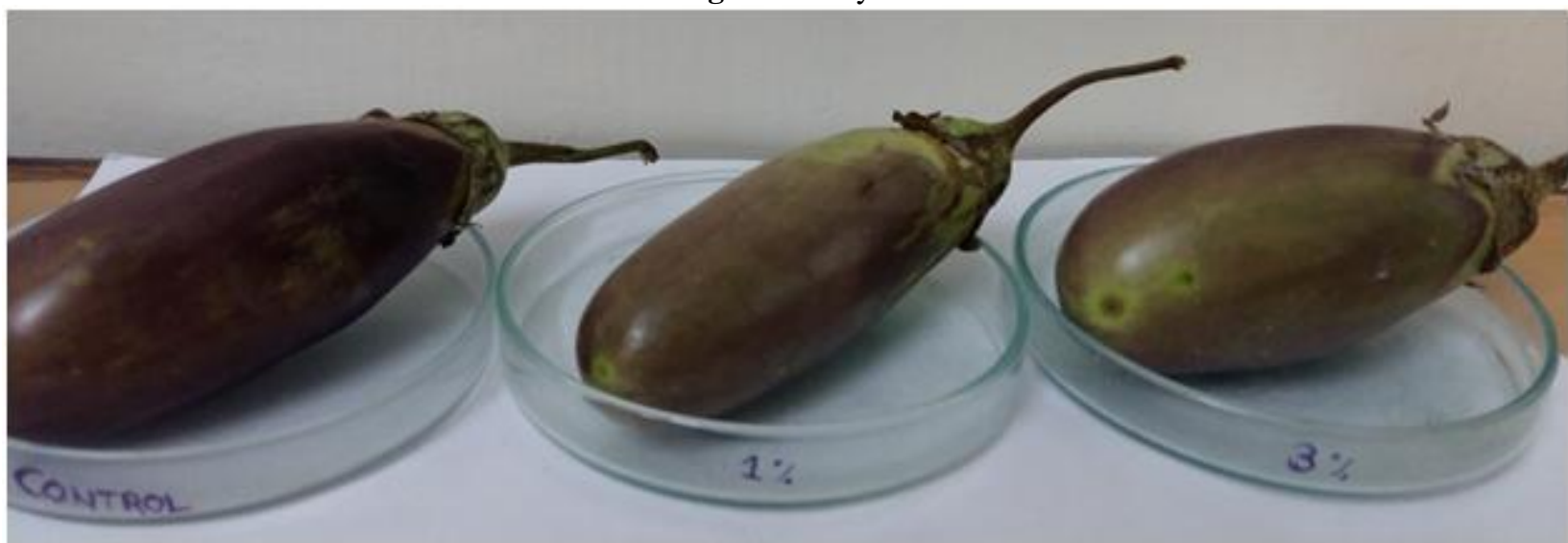

Volume 6 Issue 7, July 2017

www.ijsr.net

Licensed Under Creative Commons Attribution CC BY 
International Journal of Science and Research (IJSR)

ISSN (Online): 2319-7064

Index Copernicus Value (2015): 78.96 | Impact Factor (2015): 6.391

Figure 7: Day 7

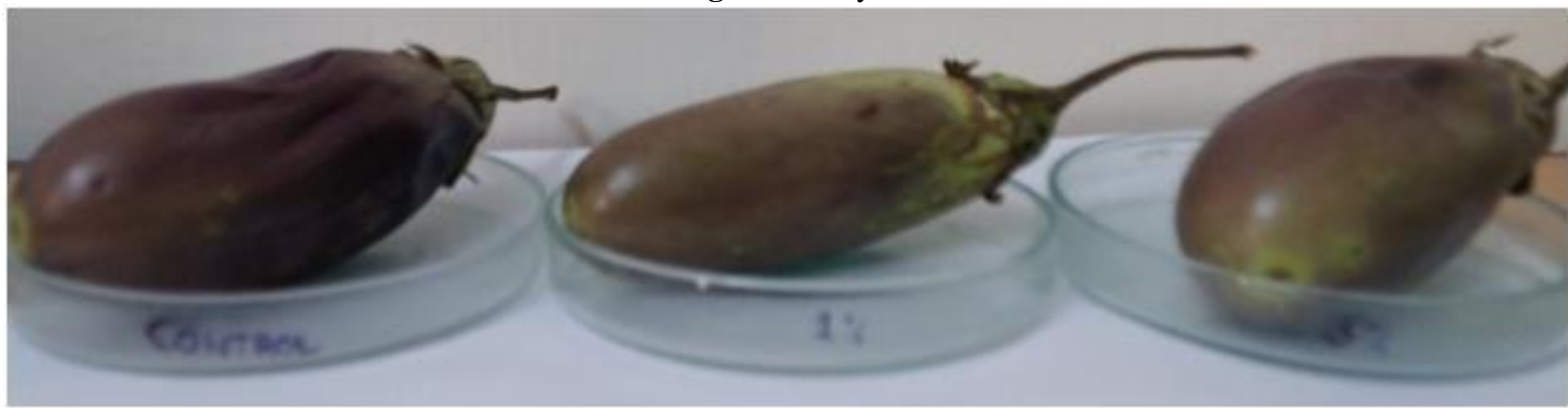

Figure 8: Day 8

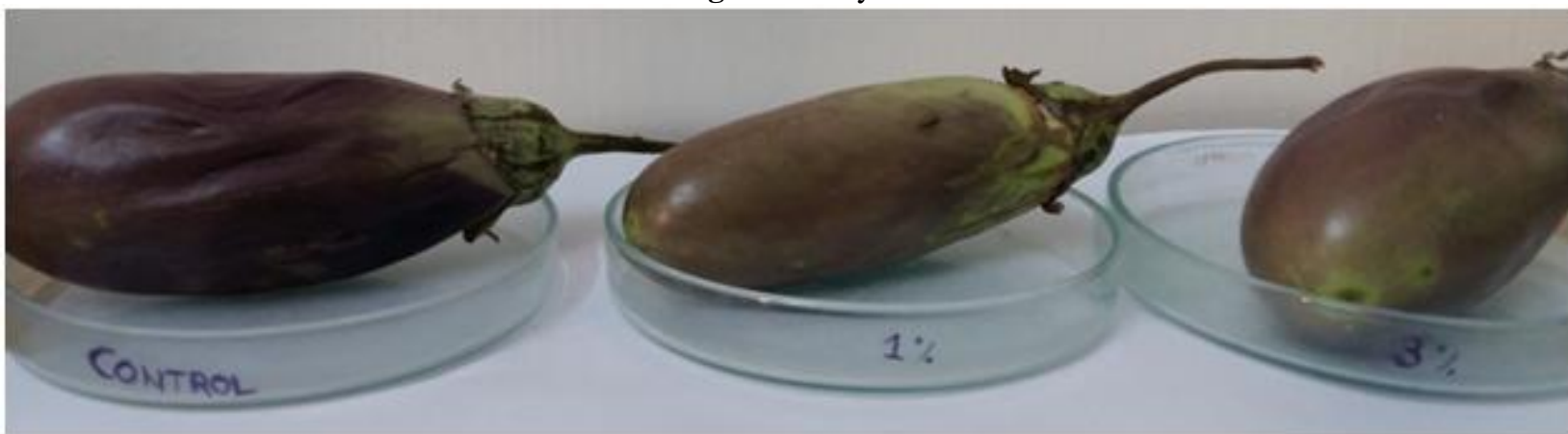

\section{CAPSICUM}

Figure 9: Day 1

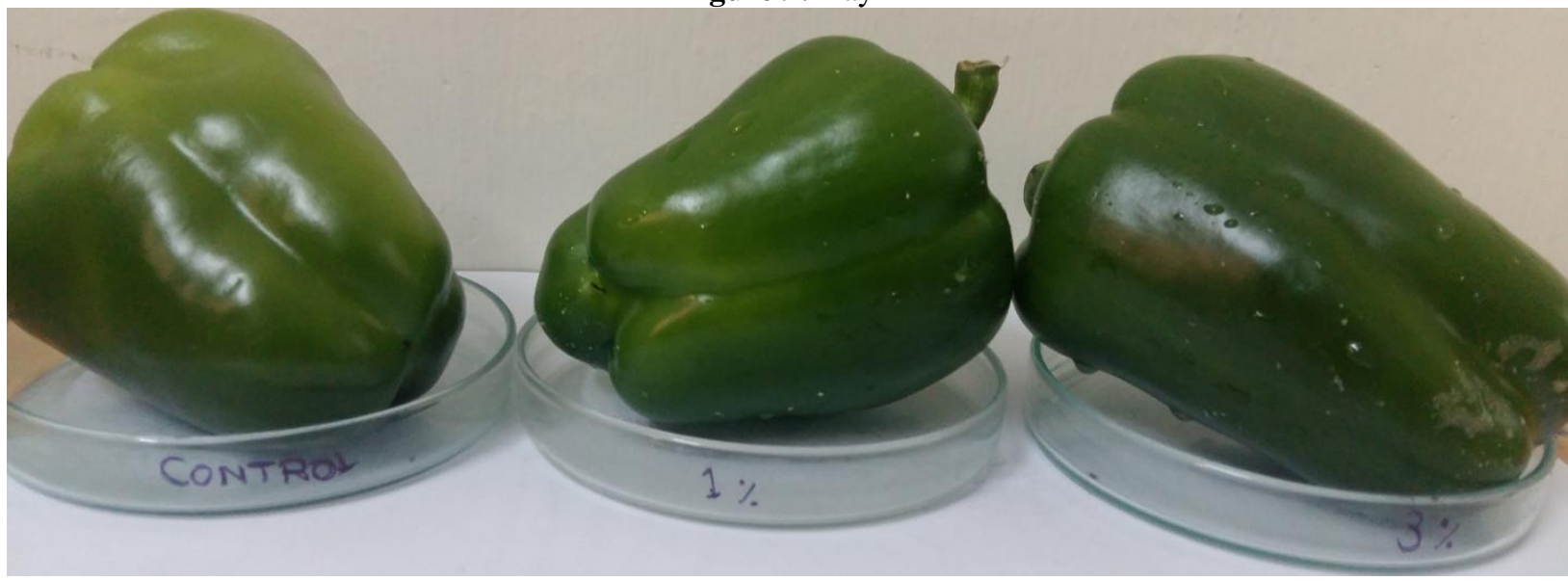

Figure 10: Day 2

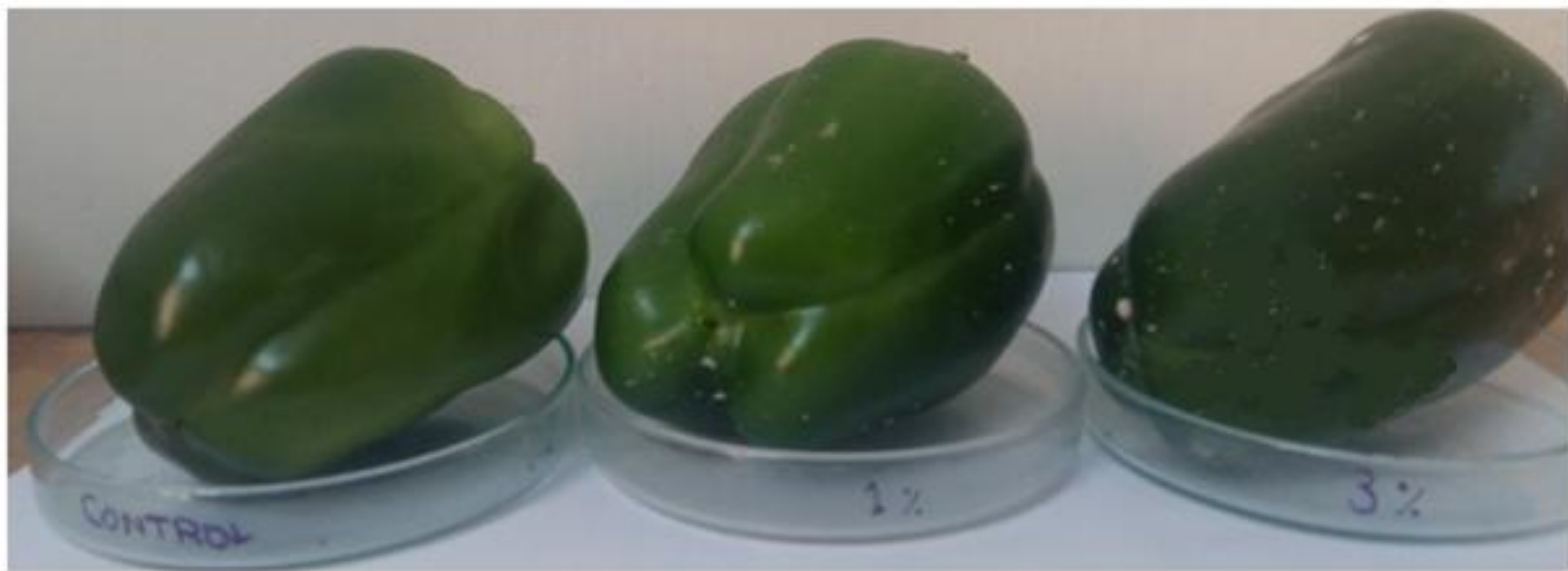

Volume 6 Issue 7, July 2017

www.ijsr.net

Licensed Under Creative Commons Attribution CC BY 
International Journal of Science and Research (IJSR)

ISSN (Online): 2319-7064

Index Copernicus Value (2015): 78.96 | Impact Factor (2015): 6.391

Figure 11: Day 3

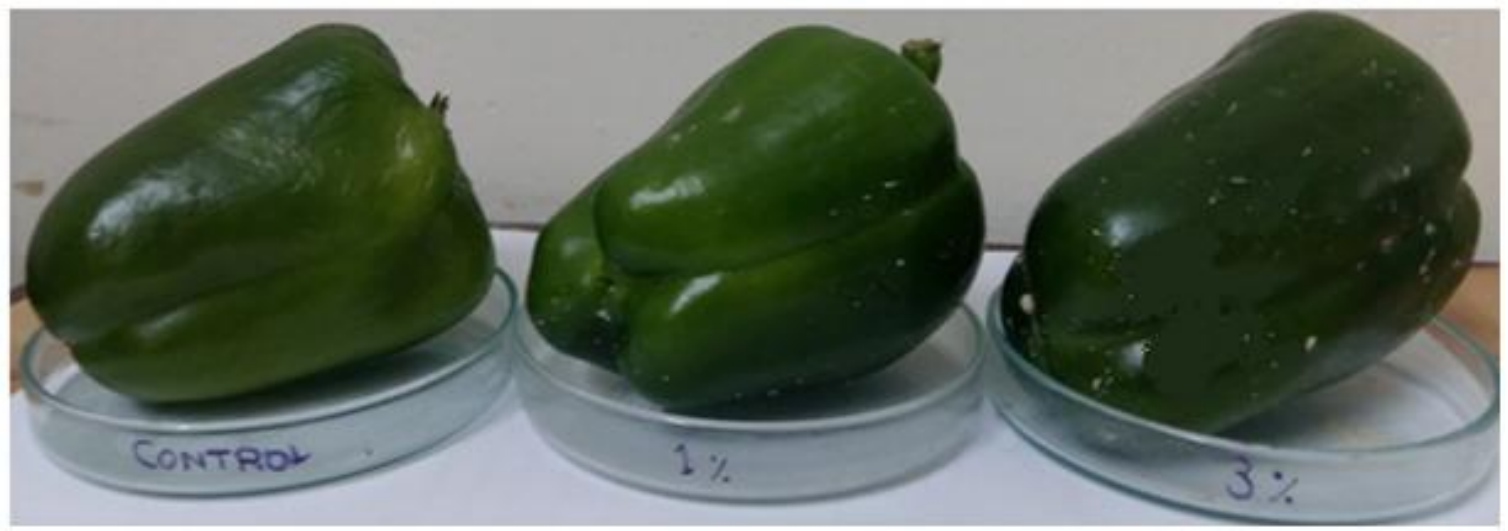

Figure 12: Day 4

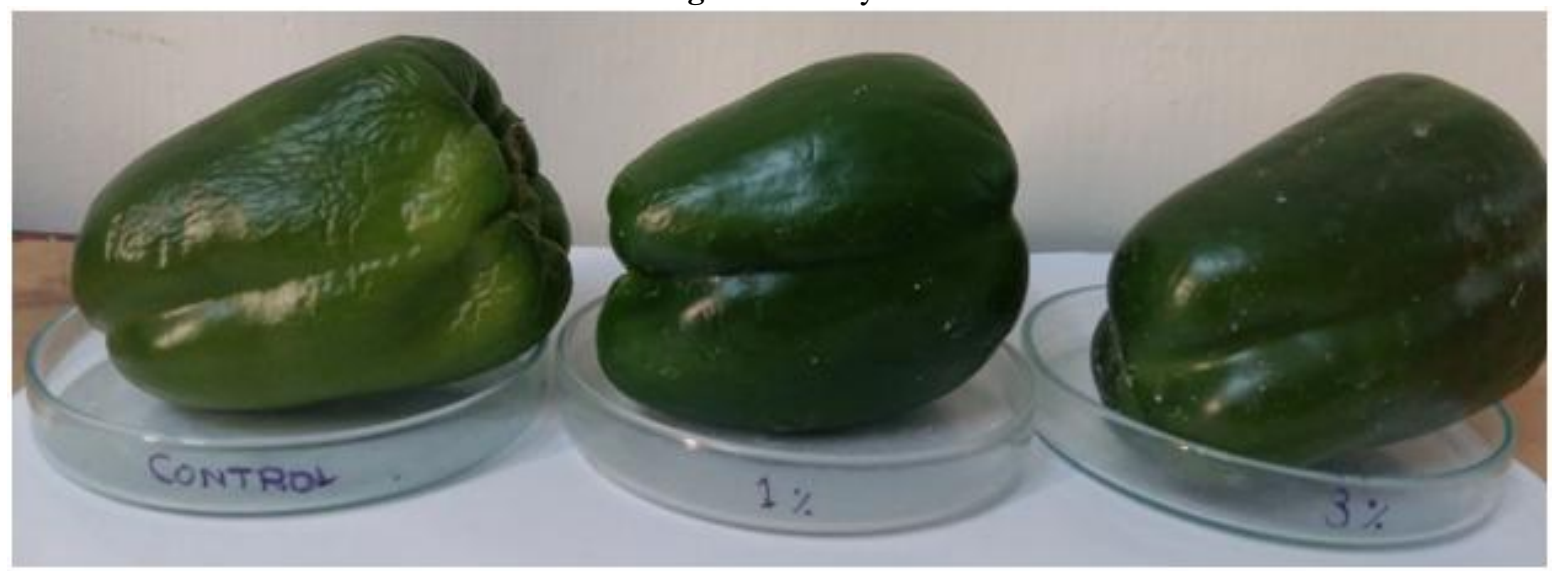

Figure 13: Day 5

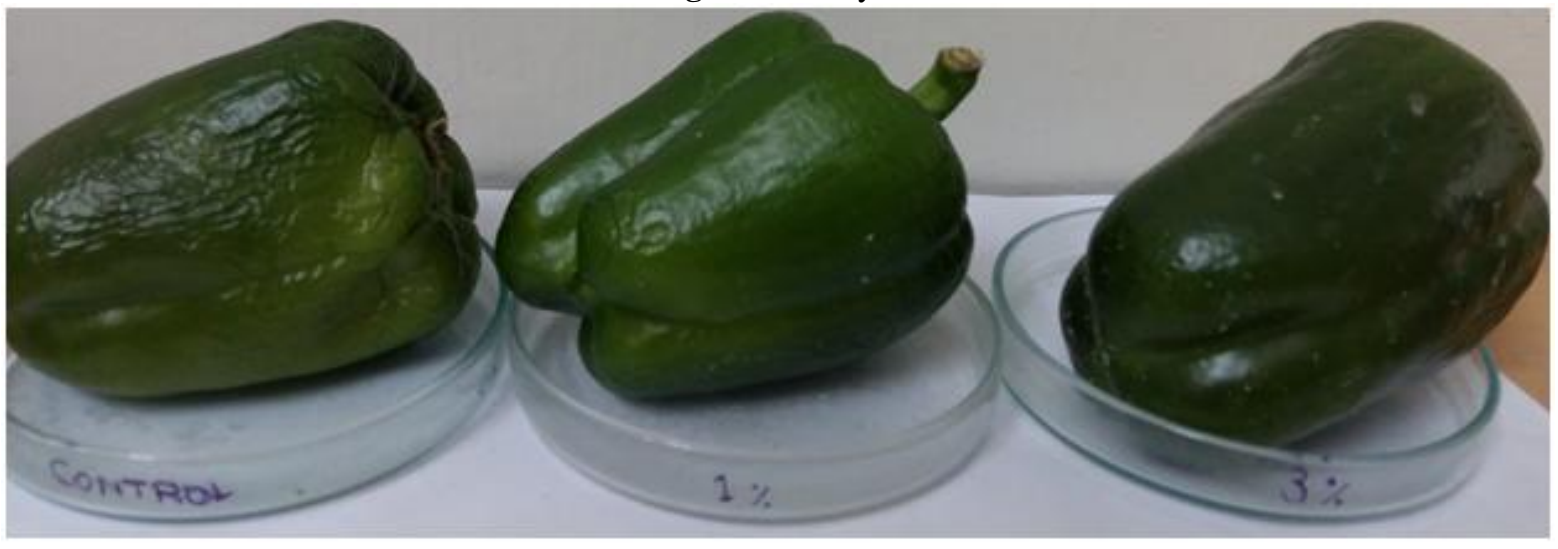

Figure 14: Day 6

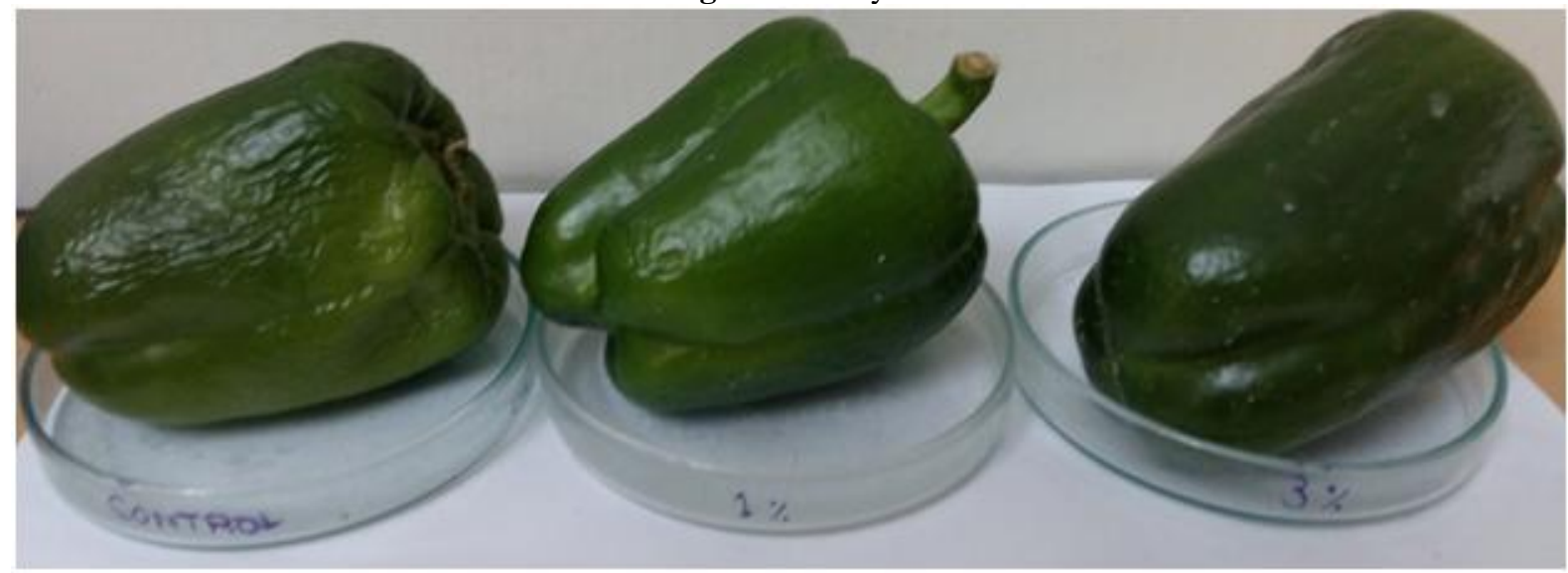

Volume 6 Issue 7, July 2017

www.ijsr.net

Licensed Under Creative Commons Attribution CC BY 
International Journal of Science and Research (IJSR)

ISSN (Online): 2319-7064

Index Copernicus Value (2015): 78.96 | Impact Factor (2015): 6.391

Figure 15: Day 7

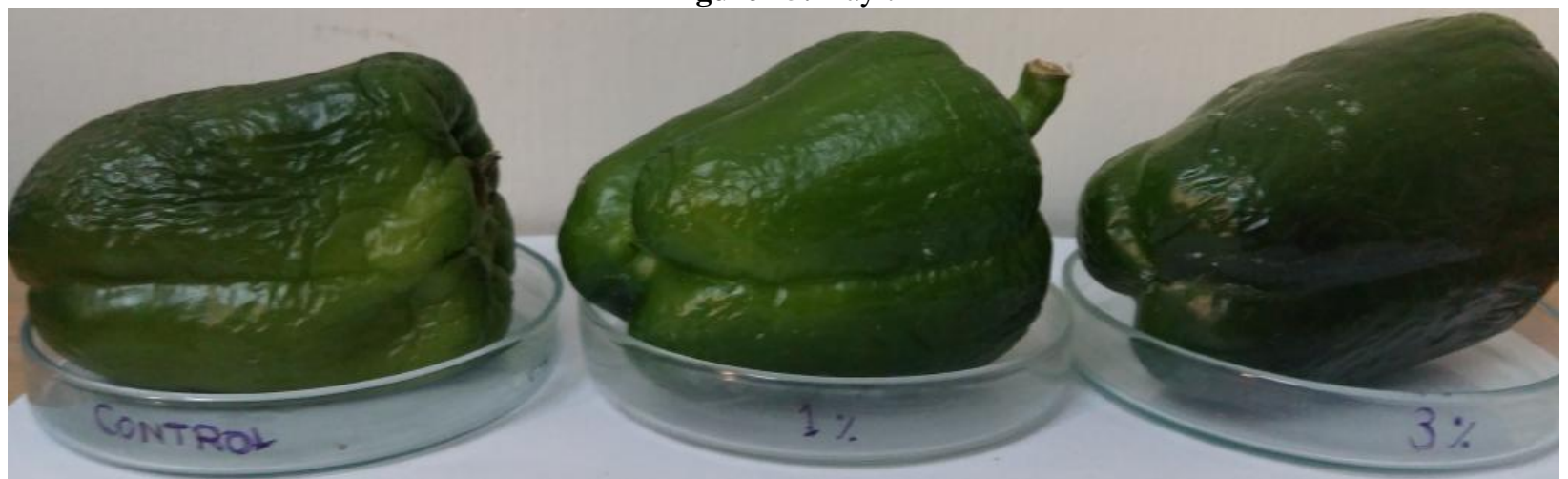

Figure 16: Day 8

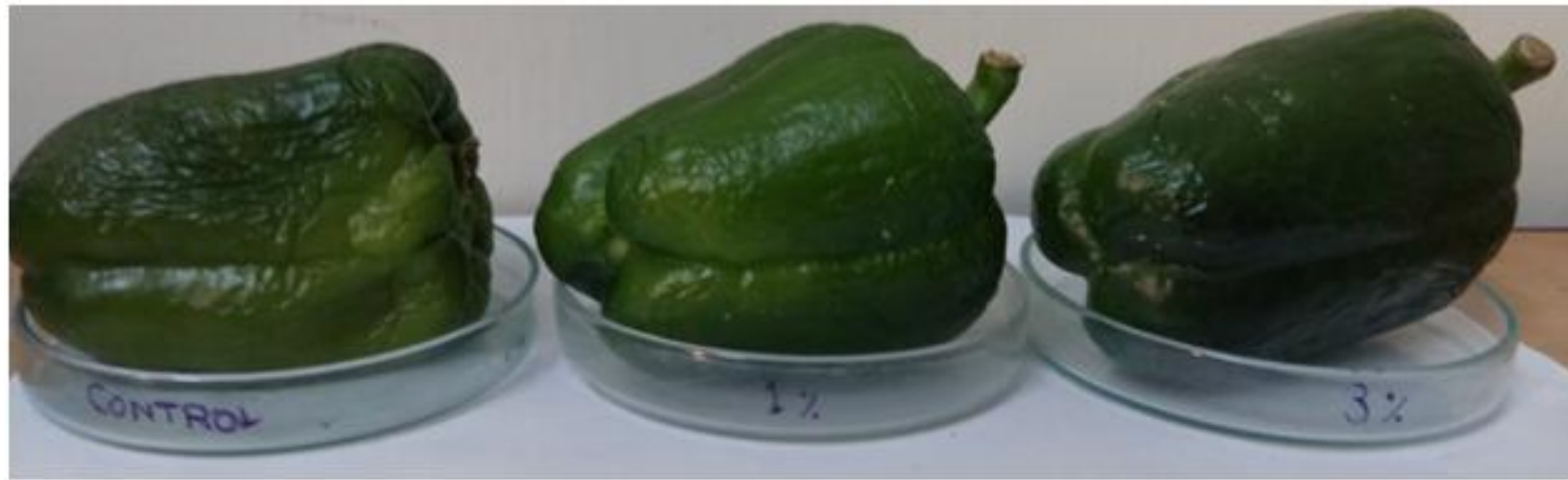

TOMATO

Figure 17: Day 1

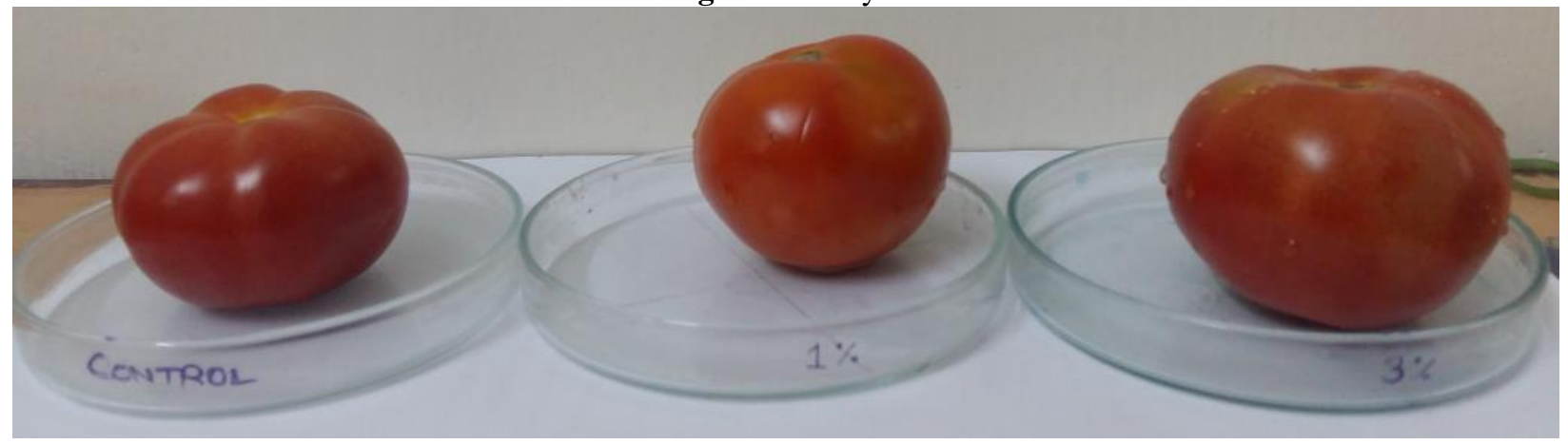

Figure 18: Day 2

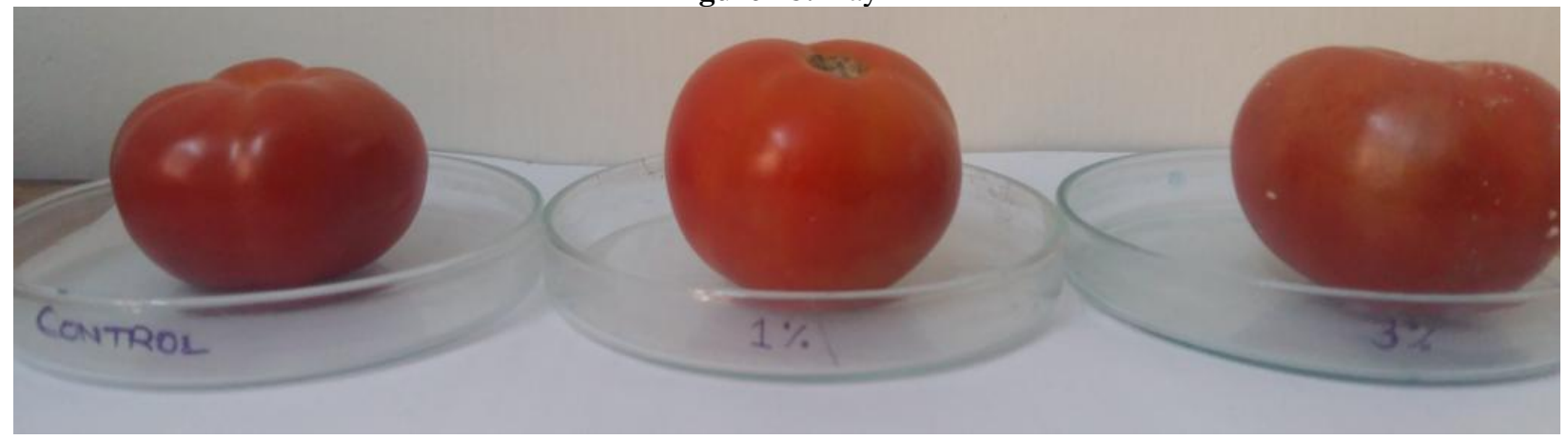

Volume 6 Issue 7, July 2017

www.ijsr.net 
International Journal of Science and Research (IJSR)

ISSN (Online): 2319-7064

Index Copernicus Value (2015): 78.96 | Impact Factor (2015): 6.391

Figure 19: Day 3

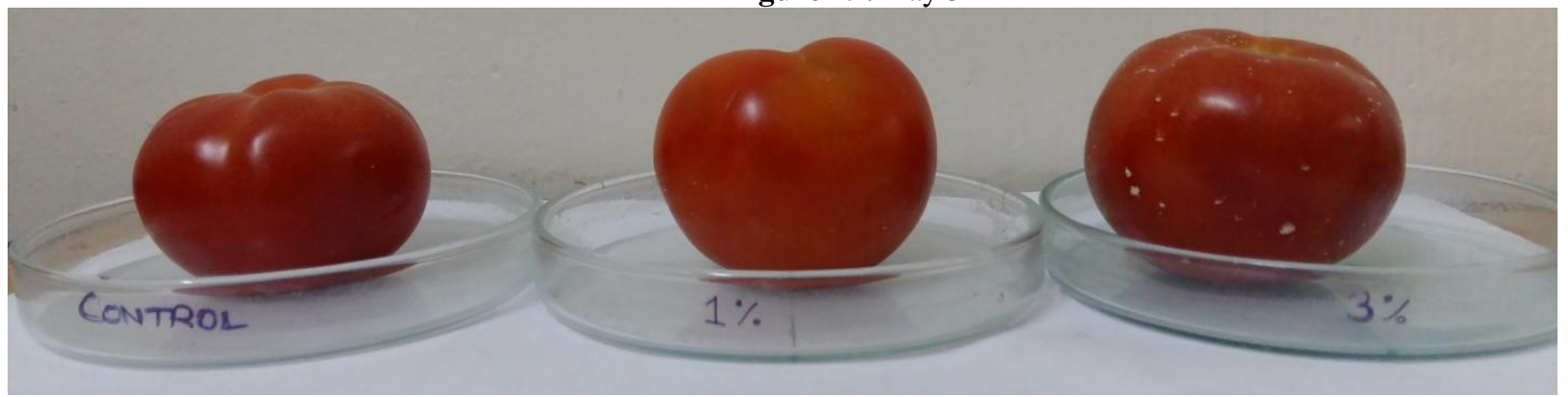

Figure 20: Day 4

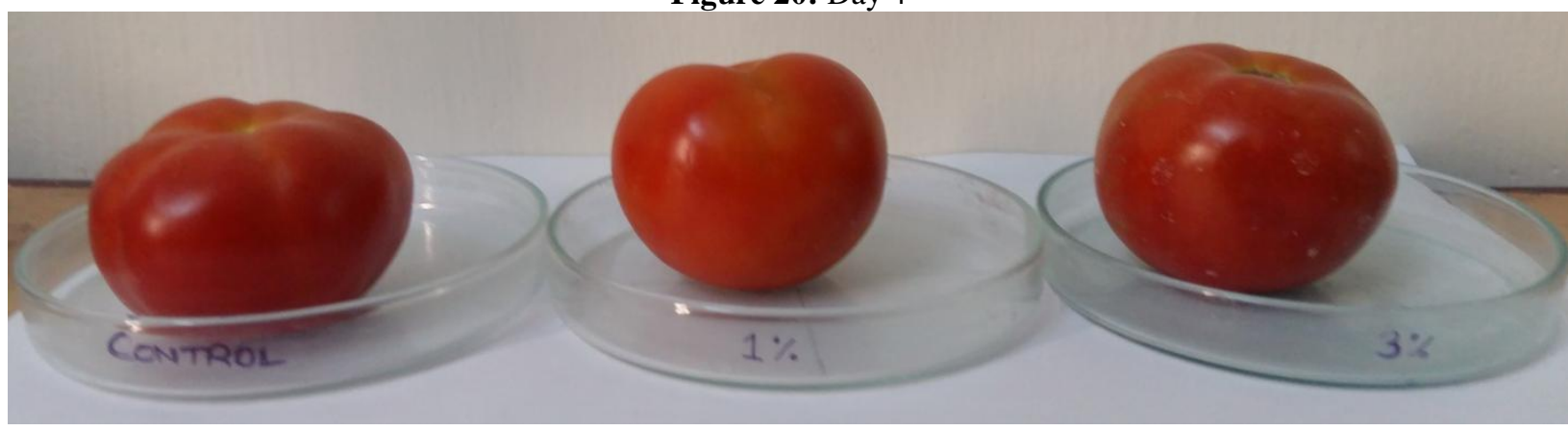

Figure 21: Day 5

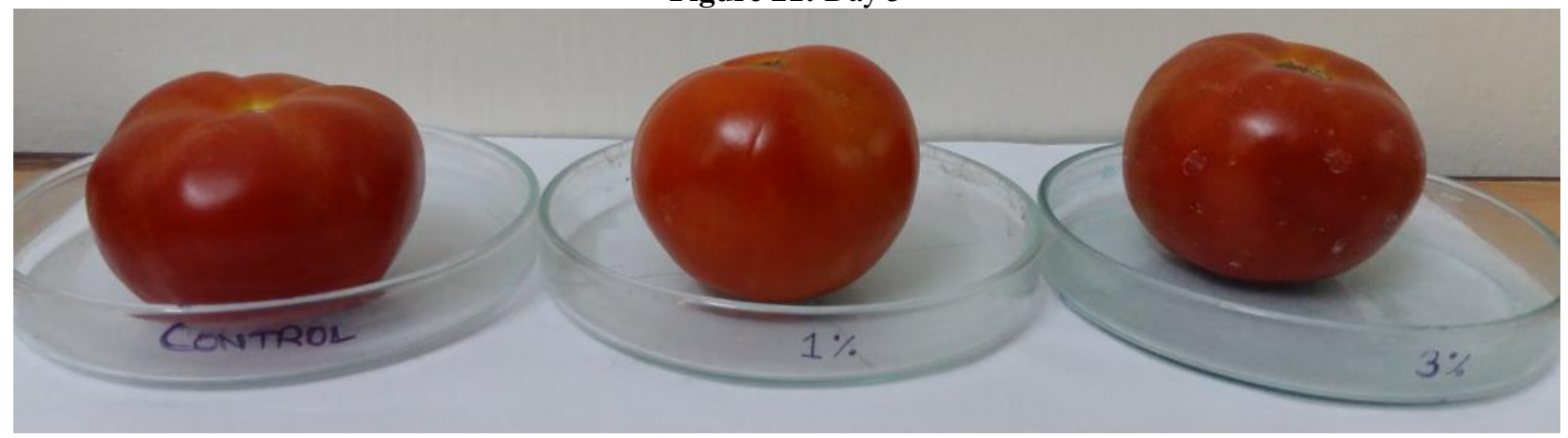

Figure 22: Day 6

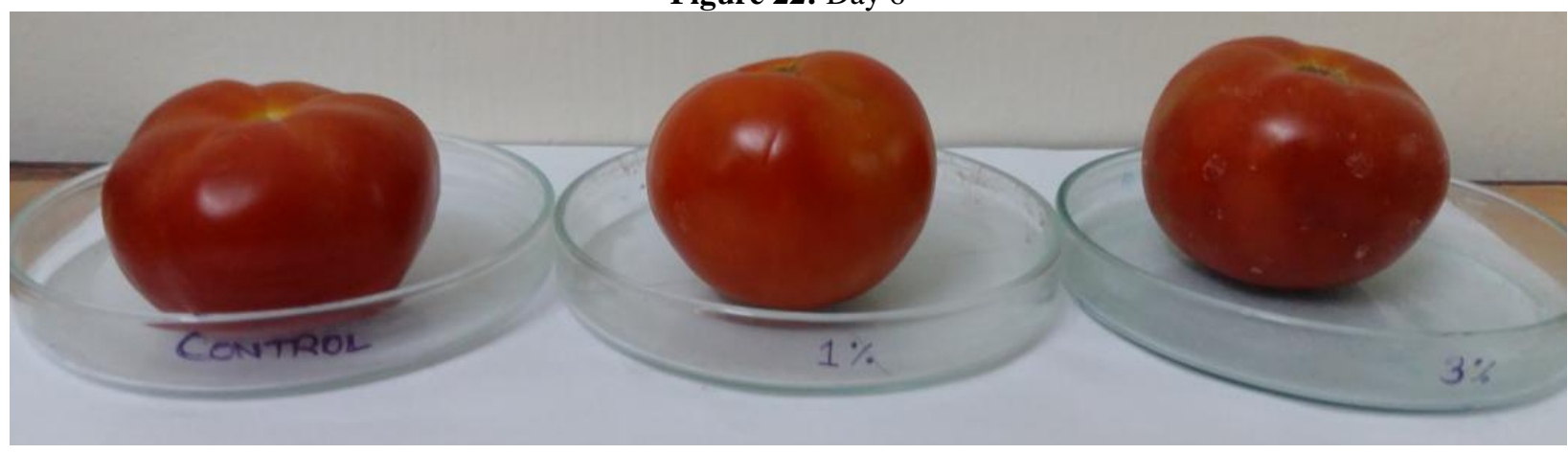

Figure 23: Day 7

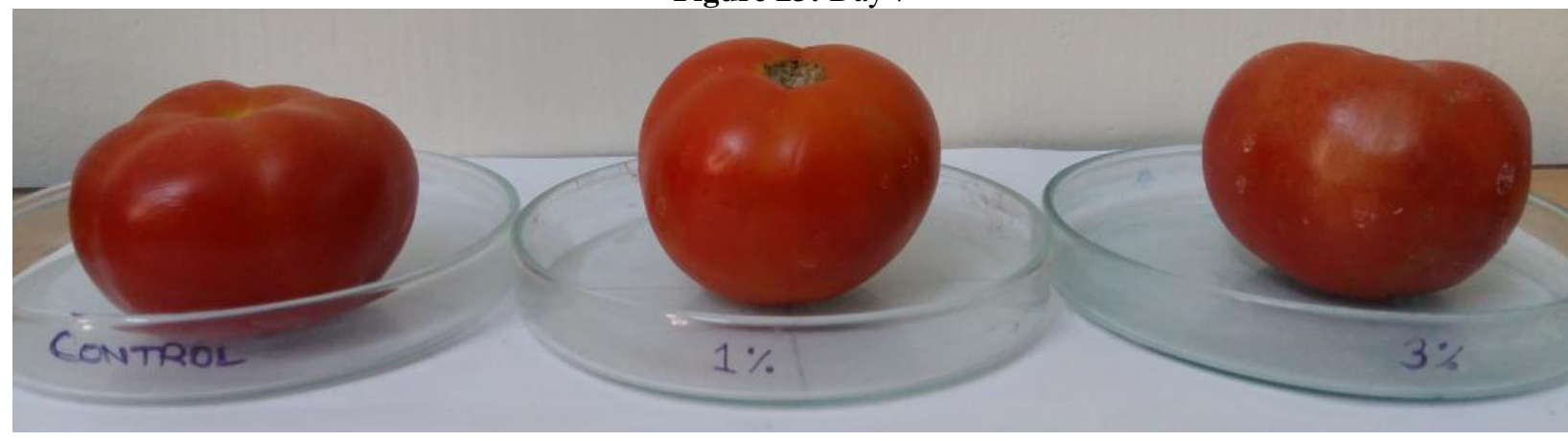

Volume 6 Issue 7, July 2017

www.ijsr.net

Licensed Under Creative Commons Attribution CC BY 


\section{International Journal of Science and Research (IJSR) \\ ISSN (Online): 2319-7064}

Index Copernicus Value (2015): 78.96 | Impact Factor (2015): 6.391

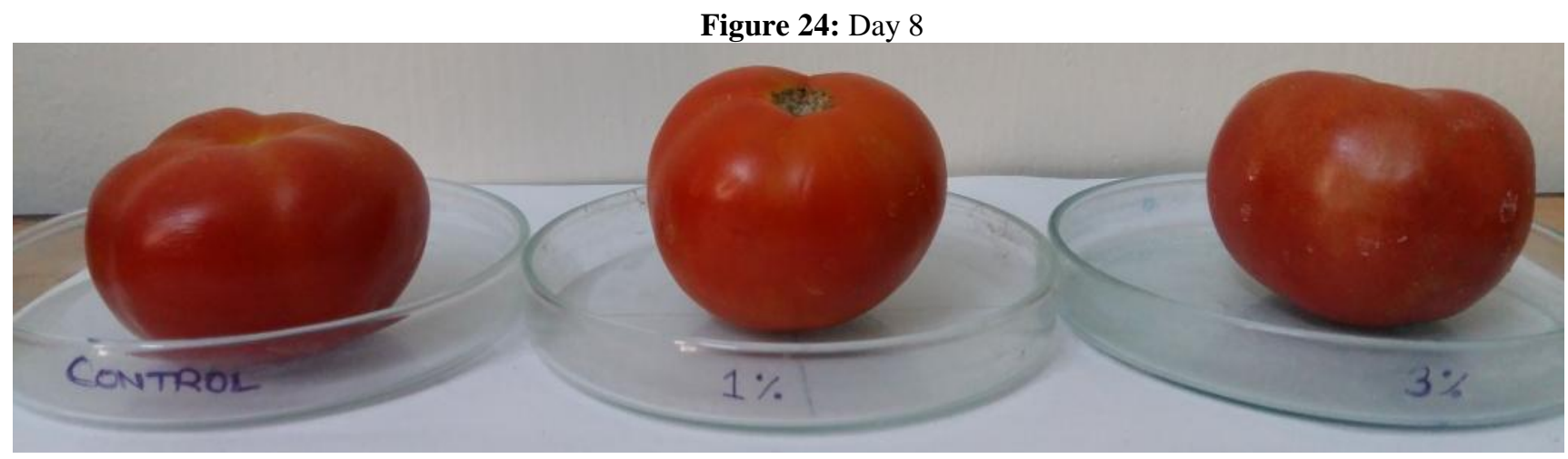

It can be inferred from the above results that the Chitosan coating on the tomatoes, brinjal and capsicum delayed the signs of aging namely, formation

Ghaouth (1992) [10] studied the effect of Chitosan coating on the storage life of tomatoes and observed that Chitosan derived coatings delayed ripening and reduced decay incidence in tomato fruit. Ghaouth (1992) [10] also carried out similar studies on cucumber and bell pepper fruits to analyse the effect of Chitosan coating on water loss and quality maintanence. It was observed that Chitosan was a potential preservative as it reduced the weight loss and improved the appearance. The results of this study were found to be in accordance with it. However, there has been no previous work of this nature carried out on brinjal.

Thus from this study, it can be concluded that the spraying of Chitosan on tomato, capsicum and brinjal has delayed the signs of aging namely, formation of wrinkles, softening of the skin texture, reduction in weight and sometimes change in colour. It is also notable that higher percentage of Chitosan $(3 \%)$ has not had any significant difference than the lower percentage of Chitosan (\%1). Hence Chitosan at lower percentage can be used for food preservation.

\section{References}

[1] Morris. L.L. Chilline injury of horticultural crops: An overview. Hort Science 17, pp161-162, 1982.

[2] Kader, A., D. Zagory, and E. Kerbel. Modified atmosphere packaging of fruits and vegetables. CRC Crit. Rev. Food Nutr. 28, pp 1-30, 1989.

[3] Banks, N.H. Some effects of TAL Pro-Long coating on ripening bananas. J. Expt. Bot. 35, pp 127-137, 1984.

[4] Banks, N.H. Internal atmosphere modification in ProLong coated apples. Acta Hort. 517, pp 105-112, 1985.

[5] Hadwiger, L.A., S.J. Klosterman and J.J. Choi,. The Mode of Action of Chitosan and oligomers in Inducing Plant Promoters and Developing Disease Resistance in Plant. In: Advances in Chitin Sciences, Suchiva, K., S. Chandkrachang, P. Methacanon and M.G. Peter (Eds.)/ Vol. 5, Chulalongkorn University, Bangkok, Thailand, pp: 458-457, 2002.

[6] Muzzarelli, R.A.A. Filmogenic properties of chitin/chitosan, In R. Muzzarelli, C. Jeuniaux, and G.W. Gooday (eds.).Chitin in nature and technology. Plenum Press, New York, pp. 389-396, 1986.

[7] Khin, L.N., N.Nitar, S. Chandrkrachang and F.S.Willem, Chitosan asa growth stimulator in orchid tissue culture. Plant Sci., 170, pp 1185-1190, 2006.
[8] Hirano, S., C. Itakura, H. Seino, Y. Akiyama, I. Nonaka, N. Kanbara, and T. Kawakami. Chitosan as an ingredient for domestic animal feeds. J. Agr. Food Chem. 38, pp 1214-1217, 1990.

[9] Cheah, L.H., Page, B.B.C., and Shepherd, R.. Chitosan coating for inhibition of sclerotinia rot of carrots, New Zealand Journal of Crop and Horticultural Science, 25:1, pp 89-92, 1997

[10]El Ghaouth, A.; Ponnampalam, R.; Castaigne, R; Arul, J. Chitosan coating to extend the storage life of tomatoes. HortScience 27: pp 1016-1018, 1992.

[11] Hadwiger, L. A.; Beckman, J. M.: Chitosan as a component of pea-Fusarium solani interactions. Plant physiology 66, pp 205-211, 1980.

[12]El Ghaouth, A.; Arul, J.; Ponnampalam, R.: Use of chitosan coating to reduce water loss and maintain quality of cucumbers and bell pepper fruits. Journal of food processing and preservation 15, pp 359-368, 1991

[13] Stossel, P. and J.L. Leuba.. Effect of chitosan, chitin and some aminosugars on growth of various soilbome phytopathogenic fungi. Phytopathol. Z. 111, pp 82-90, 1984. 